\title{
A "Leaky" Pipeline and Chilly Climate in Archaeology in Canada
}

\author{
Lisa Overholtzer (iD) and Catherine L. Jalbert
}

\begin{abstract}
This article quantifies the rate at which women archaeologists are present and retained in university departments. Drawing on publicly available data, we examine gender representation in (1) doctorates earned between 2002-2003 and 2016-2017; (2) Social Sciences and Humanities Research Council (SSHRC) grant applications and awards at the doctoral to senior levels between 2003 and 2017; (3) tenure-stream faculty at Canadian universities in 2019; and (4) placement of Canadian PhDs in the United States. These data demonstrate that women today represent two-thirds of all Canadian doctorates in archaeology, but only one-third of Canadian tenure-stream faculty, although not all archaeologists choose an academic career. In the last 15 years, women with Canadian PhDs have been hired into tenure-track positions in Canada at rates statistically lower than men, but at higher rates in the United States. Women apply for SSHRC archaeology grants in equal proportion to their presence, but men are awarded at a slightly higher rate. We end by discussing the possible reasons for this gendered attrition, including a "chilly climate"that is, subtle practices that stereotype, exclude, and devalue women, as well as inhospitable working environments, particularly for primary caregivers. We warn that the current COVID-19 pandemic is likely to exacerbate these existing inequalities.
\end{abstract}

Keywords: gender, equity, diversity, bias, epistemology, universities, academia, archaeology, Canada

Cet article quantifie l'incapacité de l'archéologie universitaire à retenir les femmes au Canada. Il s'appuie sur des données publiques concernant : (1) les doctorats en archéologie obtenus entre 2002-2003 et 2016-2017; (2) les demandes de subventions en archéologie du Conseil de recherches en sciences humaines (SSHRC) et de bourses accordées aux niveaux de la recherche doctorale, postdoctorale et supérieure entre 2003 et 2017 ; (3) des professeurs d'archéologie (adjointe, associé et titulaire) dans les universités canadiennes en 2019 ; et (4) le placement des titulaires d'un doctorat canadien aux ÉtatsUnis. Ces données démontrent que les femmes reçoivent aujourd'hui les deux tiers des doctorats en archéologie, mais représentent seulement un tiers des professeurs. Au cours des quinze dernières années, les femmes titulaires d'un doctorat canadien ont été embauchées à des postes permanents au Canada à des taux statistiquement inférieurs à ceux de leurs homologues masculins, ce qui laisse entrevoir la possibilité d'un biais systématique lors de l'embauche. Les femmes sollicitent des subventions du SSHRC en proportion égale par rapport à leur présence à chaque niveau; cependant, à chaque niveau les projets dirigés par des hommes ont eu légèrement plus de succès que ceux des femmes. L'article se termine par une discussion sur les raisons possibles de l'attrition de femmes de la discipline, y compris un "climat froid" pour les femmes, faisant référence à des pratiques subtiles et non discursives qui stéréotypent, excluent et dévalorisent les femmes, et à un environnement de travail inhospitalier pour les familles et disproportionnément pour les mères universitaires. Nous avertissons également que la pandémie actuelle de COVID-19 risque d'aggraver ces inégalités existantes.

Mots clés: sexospécificité, parité, diversité, préjugé, épistemologie, universités, l'Académie, archéologie, Canada

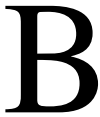

eginning with the rise of engendered archaeologies in the 1980s and 1990s, a growing number of scholars have turned their lenses inward to examine the gendered social realities of our own discipline (Claassen 1994; du Cros and Smith 1993; Gero 1985,

Lisa Overholtzer (lisa.overholtzer@ mcgill.ca, corresponding author) — Department of Anthropology, McGill University, 855 Sherbrooke Street West, Montreal, Quebec H3A 2T7, Canada

Catherine L. Jalbert $\boldsymbol{\square}$ Historic Sites Division, Texas Historical Commission, PO Box 12276, Austin, Texas 78711, USA (catherine.jalbert@thc.texas.gov)

American Antiquity 86(2), 2021, pp. 261-282

Copyright (C) The Author(s), 2021. Published by Cambridge University Press on behalf of the Society for American Archaeology. This is an Open Access article, distributed under the terms of the Creative Commons Attribution licence (http://creative commons.org/licenses/by/4.0/), which permits unrestricted re-use, distribution, and reproduction in any medium, provided the original work is properly cited.

doi:10.1017/aaq.2020.107 
1991, 1996; Handly 1995; Hutson 1998, 2002; Ikawa-Smith 2002; Kramer and Stark 1988; Nelson et al. 1994; Stark et al. 1997; Victor and Beaudry 1992; Walde and Willows 1991; Zeder 1997a, 1997b). As is broadly the case in gendered studies of academia (Chilly Collective 1995), Canadian archaeology was at the forefront of this move: the edited volume for the 1989 gender-themed Chacmool conference (Walde and Willows 1991) featured eight articles on gender equity in North American archaeology. They identified significant gendered disparities in hiring, funding, publication, and citation rates. Because science benefits from the inclusion of previously marginalized perspectives that can help question long-standing assumptions and biases (Wylie 2011, 2013), these findings are of epistemological concern. Moreover, universities increasingly recognize the importance of having faculties that reflect the diversity of student bodies across many axes of intersecting identities (e.g., gender, race/ethnicity, sexual orientation, class, [dis]ability), because faculty members are role models who can either expand or contract student career aspirations.

Recently, many American scholars have begun to assess progress in recent decades (Bardolph 2014; Bardolph and VanDerwarker 2016; Fulkerson and Tushingham 2019; Goldstein et al. 2018; Heath-Stout 2019; Jalbert 2019; Rautman 2012; Speakman, Hadden, Colvin, Cramb, Jones, Jones, et al. 2018; Speakman, Hadden, Colvin, Cramb, Jones, Kling, et al. 2018; Tushingham et al. 2017). ${ }^{*}$ Similarly, we wondered what progress had been made in Canada since the most recent publications in the 1990s (Bernick and Zacharias 1995; Handly 1995; Kelley and Hill 1994). We also wanted to understand whether differences exist between Canada and the United States given the significant movement of scholars in both directions for graduate school and academic positions.

Overholtzer, an example of this movement and a recent arrival to Canada herself, wanted to better understand the milieu in which she was situated, and the academic career pathway through which she was guiding her doctoral

*An endnote has been removed since the article's original publication. See 10.1017/aaq.2021.24. students, all of whom had career goals in higher education. She is a white, straight, cisgendered, American scholar-wife-mother on the tenure track at McGill University, and she has personally benefited from Canada's progressive, family-friendly policies. These include paid parental leave and subsidized childcare, McGill University's spousal hiring program, and generous research funding from the liberal federal government. While teaching the seminar on Gender and Sexuality in Archaeology at McGill, she was unable to find any recent publications on diversity and equity issues within the Canadian context that she could assign. Consequently, her part of this study was born. Because her own archaeological experience is limited to academic contexts, so too was her study.

Jalbert, who also identifies as a white, cisgendered woman, chose a CRM career. As a dual citizen, she has had the privilege of pursuing studies and work both in the United States and Canada. She recently completed her dissertation at Memorial University of Newfoundland and currently calls Texas home. Her dissertation addressed some of the very questions pondered by Overholtzer, examining demographics and working conditions in archaeological education and employment through a feminist, intersectional lens. Jalbert came to this research topic through her doctoral comprehensive exams. Because of her situatedness in the discipline, she has always been interested in the production of knowledge, particularly from the perspective of CRM.

Like many women studying archaeology, the authors suffered negative experiences, such as gender-based discrimination and harassment in the field, which influenced their choice of career paths and led to their commitment to promoting more equitable workplaces. Overholtzer was motivated to stay in academia, conduct research and teach on gender in the discipline, and direct field projects that would provide safe spaces for all students-following the example of her advisers, all of whom were women. Jalbert's experiences cemented her decision to remain in CRM. In her work, she aims to support students who are interested in exploring their opportunities outside of an academic career path. These shared experiences and diverse perspectives are brought together in this article to 
assess the current state of affairs in archaeology in Canada.

\section{Academic Archaeology Turns a Gendered Lens in on Itself}

The conclusions reached by the initial generation of scholars in the 1980s and 1990s, using empirical datasets-ranging from grant, publication, and citation rates to representation in tenure-track university positions-are striking. Although most of this research focused on the United States, these data provide a useful point of comparison for Canada because, as this article will show, many academics move across the border in both directions for tenure-track positions. Yellen (1994) documented the attrition of women archaeologists in the United States, or what can be called a "leaky pipeline," from a majority of National Science Foundation (NSF) grant applicants at the doctoral level (54\%) to only $26 \%$ at the senior level. Several studies found that despite greater parity in graduate degree attainment, women were not hired into permanent academic positions at rates proportionate to their presence in $\mathrm{PhD}$ cohorts (Hutson 1998; Stark et al. 1997; Zeder 1997a, 1997b). Women were also less successful in funding their research, less productive as measured by publication rates, undercited, and less satisfied in their positions (Beaudry and White 1994; Hutson 2002; Zeder 1997a, 1997b).

More recent studies in the United States have confirmed that these problems continue, despite increased awareness and in the face of a growing (albeit minority) sentiment that men in STEM fields now suffer from "reverse discrimination" (Funk and Parker 2018). In the United States, gender disparities remain in tenure-track archaeology hiring (Goldstein et al. 2018; Speakman, Hadden, Colvin, Cramb, Jones, Jones, et al. 2018; Speakman, Hadden, Colvin, Cramb, Jones, Kling, et al. 2018), senior research grant submissions (Goldstein et al. 2018), and participation in conferences and publishing in peerreviewed journals, especially those with high impact factors (Bardolph 2014; Bardolph and VanDerwarker 2016; Fulkerson and Tushingham 2019; Gamble 2020; Heath-Stout 2019, 2020a, 2020b; Rautman 2012; Tushingham et al. 2017).
Despite women constituting the majority of U.S. PhD recipients in archaeology since 2002 (Tushingham et al. 2017:Figure 1), men still hold $65 \%$ of American academic positions, and they are particularly overrepresented at universities with graduate programs (Goldstein et al. 2018:374, Figures 5 and 6). Moreover, analysis of hiring in the United States (2004-2014) revealed that, in comparison to $\mathrm{PhD}$ graduation rates, men were disproportionately hired into research-intensive positions, especially those with doctoral programs (Speakman, Hadden, Colvin, Cramb, Jones, Kling, et al. 2018:6; see also Speakman, Colvin, Cramb, Jones, Jones, et al. 2018). Given the underrepresentation of women in research-intensive positions, it is not surprising that the number of submissions by senior archaeology women to the U.S. NSF between 2009 and 2013 was half that of men.

Comparatively little is known about the status and success of women in academic archaeology in Canada today (Jalbert 2019; for Canadian studies in other disciplines, see Adamo 2013; Tamblyn et al. 2018; Titone et al. 2018). Kelley and Hill (1994) provide historical data for archaeology graduate training and career placement in Canada. Their analysis of graduate program statistics from the University of Calgary between 1966 and 1990 revealed that women withdrew at higher rates than men (36\% vs. $24 \%)$ and that fewer women went into full-time academic positions (17\% vs. 36\%). Women made up only $20 \%$ of the assistant professors of archaeology in Canadian institutions listed in the 1989-1990 AAA AnthroGuide $(n=3)$, compared to $49 \%$ for all of anthropology. They pointed out that women were underrepresented in archaeology faculty positions with respect to their numbers in graduate programs.

Bernick and Zacharias (1995:84) found lower rates of conference participation, publication and citation rates, and fieldwork permits among women, as well as a "near absence" of seniorlevel women in British Columbia archaeology. Handly's (1995) review of the Canadian Journal of Archaeology (1969-1993) found a historical increase in articles authored by women-up to $37 \%$ in the last five years. He found a positive correlation between editorial staff positions occupied by women and acceptance of women's 
articles, suggestive of the role of gendered marginalization and academic gatekeeping (Handly 1995:72). Furthermore, he found no increase in the proportion of women asked to review archaeology books, which suggests that they were still not assumed to be authorities within their academic specialization (Handly 1995:72). Recently, Jalbert (2019) conducted a mixedmethods study that included education and employment data, surveys, and interviews with women archaeologists. She concluded that although more women are entering the field at all levels and within all sectors, they are not retained in upper-level positions across academic and CRM workplaces.

These findings are broadly supported within Canadian academia (Drakich and Stewart 2007; Ornstein et al. 2007; Stewart et al. 2009). Despite dramatic increases in the representation of women in Canadian graduate programs from the mid-1980s to $1990 \mathrm{~s}$, there have been more modest gains in their appointment to faculty positions, the speed of their promotion to associate professor, their advancement to full professor, and their representation as Canada Research Chairs. The 2018 equity report of the Canadian Association of University Teachers (CAUT) confirms this slow progress: women represented $48.5 \%$ of assistant professors in $2016 / 2017$ compared to $42.9 \%$ in $2006 / 2007$, and $27.6 \%$ of full professors in 2016/2017 compared to $20.3 \%$ in $2006 / 2007$.

For this study, we requested data on archaeology PhDs conferred annually to men and women in Canada between 2003 and 2016 from Statistics Canada. We followed the trajectory of these PhDs to the faculty level by surveying tenure-track archaeology faculty across Canadian universities. We also considered movement across North America by tracking Canadian $\mathrm{PhDs}$ who were hired in the United States using the AAA AnthroGuide and by considering $\mathrm{PhD}$ institutions of Canadian faculty. We also requested data on archaeology grant applications and awards at the doctoral, postdoctoral, and senior research levels from the Social Sciences and Humanities Research Council (SSHRC), the major public research body in Canada. This article presents these findings-most notably, a quantification of the discipline's "leaky pipeline" and an evaluation of gendered differences in success rates historically. Unfortunately, our analysis of these datasets is limited because gender is presented as a binary system and does not allow for third or gender-fluid self-identification - SSHRC and Statistics Canada provide data only for "females" and "males." No nonbinary gender pronouns (e.g. they, ze), however, were observed within the faculty web pages examined to conduct the survey.

This study has major limitations that are important to acknowledge. Third-wave feminism has rightfully demanded an intersectional approach that takes account of the multiple intersecting axes of oppression that influence the likelihood that an individual will earn a $\mathrm{PhD}$ and go on to have a successful career in varied workspaces. Academia continues to struggle in recruiting and retaining a diverse workforce in terms of not only gender composition but also race and ethnicity, sexual orientation, class, parental education, and (dis)ability. In Laura Heath-Stout's (2019) survey and intersectional analysis of 1,377 archaeologists who had published in major American or British journals, $45 \%$ identified as straight, white, cisgender men and $33 \%$ as straight, white, cisgender women. Archaeology in the United States is very white, straight, and cisgender.

Two recently completed demographic surveys of Canadian archaeologists suggest that Canadian archaeology is perhaps even less diverse than its American counterpart. Of the 315 responses to Jalbert's survey (2019:155), $90 \%$ of participants identified as white, with $2 \%$ of respondents identifying as a person of color (Black, Asian, or Latin) and 2\% identifying as Indigenous (First Nations, Inuit, or Métis). Demographic information was also collected for the MeToo survey recently undertaken by the Canadian Archaeological Association (CAA) Equity and Diversity Working Group led by Lisa Hodgetts (Hodgetts et al. 2020). Of the 551 respondents, $87.3 \%$ self-identified as white-a substantially higher proportion than the $72.8 \%$ census figure for the Canadian population as a whole, and a higher percentage than the U.S. survey by the SAA or the California survey conducted by UCSB. Archaeologists of Indigenous and Latin American descent (5.3\% and 
$1.1 \%$, respectively) were present among survey respondents in similar proportions as the general Canadian population, whereas Black and Asian archaeologists $(0.0 \%$ and $2.7 \%$, respectively) were notably underrepresented. The vast majority of respondents (78.2\%) also identified as straight, whereas $10 \%$ identified as bisexual and $2.1 \%$ identified in each of the categories of gay, lesbian, and asexual.

\section{Gender Representation in Academic Archaeology in Canada}

\section{Archaeology Doctorates in Canada}

To examine the relative representation of women and men at the doctoral level, we requested data from Statistics Canada on $\mathrm{PhD}$ recipients by gender over the past 15 years for the Classification of Instructional Programs code for "Archaeology"-45.0301 (Figure 1). This code likely excludes most classical archaeologists, who should be classified under 30.2202 ("Classical, Ancient Mediterranean, and Near Eastern Studies and Archaeology") as well as bioarchaeologists, who are likely classified under 45.0202 ("Physical and Biological Anthropology"). These other subfields will only be discussed briefly here.

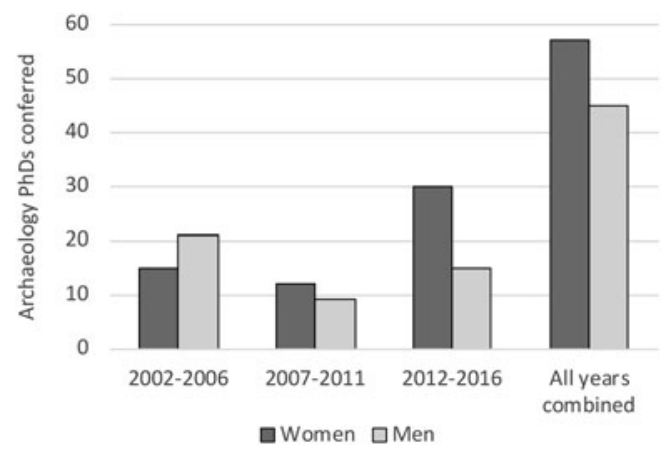

Figure 1. Archaeology doctoral graduates by gender, 2002-2003 through 2016-2017. Data provided by Statistics Canada, Postsecondary Student Information System. Note that in order to prevent the release of data that might relate to identifiable individuals, Statistics Canada rounds all values to a multiple of 3 (a value of 1 is rounded to 0 , whereas a value of 2 is rounded to 3 ). Totals are summed using true numbers, and the sum is then rounded to the nearest multiple of 3 . Because of rounding, totals may not add up to the sum of all categories.
These data reveal that women probably overtook men as the majority of doctorates in the mid-2000s. Across the entire 15-year period studied, women received 58\% of archaeology doctorates in Canada, and across the last 10 years, they received a full $64 \%$. By the last five-year period (2012-2016), women represented two-thirds of all newly minted archaeology PhDs. These data coincide with larger documented trends in archaeological education in Canada. Jalbert (2019:104-111) demonstrated that between 1992 and 2012, women represented $67 \%$ of enrollments and $68 \%$ of graduates in archaeology undergraduate programs, and they represented $64 \%$ of enrollments and $59 \%$ of master's level graduates.

Goldstein and colleagues (2018:Figure 4) similarly report that women began to earn more than $50 \%$ of the PhDs in the United States in the mid-2000s. Our Canadian data are also consistent with trends seen in National Geographic Society (NGS) applications that are correlated with the 2008-2009 economic recession. Goldstein and colleagues (2018:372) determined that NGS applicants declined overall between 2009 and 2010, but applications by women rebounded rapidly in 2011, whereas men's applications have not returned to pre-economic crisis levels. Consequently, the Statistics Canada data suggest that the recession may have also accelerated the increasing feminization of the archaeological academy in Canada.

There is no parallel in the U.S. data, however, for the dramatic increase we observe in women's representation among Canadian archaeology doctorates in the last five years. This discrepancy might reflect the fact that the U.S. data only go up to 2014 , whereas the Canadian data go up to 2017 . It is possible, then, that a similar increase will be seen in representation of women in U.S. doctorates in data released in the next few years.

\section{Archaeology Faculty in Canada}

Jalbert (2019:125) demonstrated a steady increase from 1972 to 2011 in women faculty in both anthropology and archaeology departments. Although a consistent, upward trend was less visible in archaeology, women have made substantial gains at all academic faculty 
ranks, particularly from 1990 to 2011. Nevertheless, women remained vastly underrepresented at the rank of full professor, representing only $14 \%$ between 2000 and 2011 (Jalbert 2019:Figure 5.16). This figure is far below the national average of $20 \%$ across all disciplines/universities in Canada in 2006/2007 and 23\% in 2010/2011 (CAUT 2018).

To understand the current situation, three undergraduate research assistants at McGill University conducted an online search to determine the relative representation of women and men in tenure-track positions in Canadian universities in 2019. Because the American Anthropological Association (AAA) AnthroGuide is not used extensively in Canada, we also examined university faculty web pages, using personal pronouns to identify each faculty member's gender. Because there are currently only two dedicated archaeology departments in Canada, this survey included archaeology faculty regardless of their department, which included Anthropology, Archaeology, Art History, Geography, Indigenous Studies, History, Human Sciences, Historical Sciences, Classical Studies, Greek and Roman Studies, and Near and Middle Eastern Civilizations. Our survey documented a total of 222 tenurestream archaeologists employed at 46 universities.

To facilitate comparison of our data, faculties were divided into Bioarchaeology, Classical Archaeology, and Archaeology, the latter excluding the former two subfields (Figure 2). Because bioarchaeology is often classified as a subfield of biological anthropology, and because classical archaeologists are usually not within anthropology departments, these two subfields are typically excluded from these kinds of studies. We felt, however, that there was utility in quantifying them separately in order to examine trends within specializations.

We included only individuals listed as Assistant Professor / Professeur adjoint, Associate Professor / Professeur associé, or Professor / Professeur titulaire, and we excluded individuals listed as adjunct faculty, lecturers, instructors, associate members, or emeritus. It remains possible that we missed some faculty members not listed on department websites, or that we included faculty members who recently left their positions, but we think this survey is representative of the academic situation in 2019.
Women are well represented within classical archaeology, where they represent $53 \%$ of faculty of all ranks, and especially within bioarchaeology, where they represent $69 \%$ of faculty. In our faculty survey, a larger proportion of the bioarchaeology faculty were at the assistant professor level, likely reflecting more junior hires in the past five or so years, and women filled $91 \%$ of these positions (Figure 2). Rather unsurprisingly, women are better represented at the assistant professor level in each subfield, but the increased representation in assistant and even associate levels is more marked within classical archaeology and bioarchaeology.

Women are least well represented in archaeology - only $33 \%$ of all faculty combined. As Smith similarly found 19 years after implementing a faculty equity plan at the University of Alberta, "The percentage of female faculty remains stalled at about one-third, despite the burgeoning number of female graduates" (2013:2). Women still represent only $46 \%$ of assistant professors in archaeology, and only $29 \%$ and $31 \%$ of associate and full professors, respectively. Moreover, there have been proportionately fewer tenure-track hires in this research area compared to bioarchaeology and classical archaeology. As we will discuss shortly, although a $46 \%$ representation of women at the assistant professor level reflects some advances in equity, the gender ratio of assistant professors in archaeology is lower than we would expect given the gender ratios of doctorates over the last 15 years. Given that equity targets are defined by representation proportionate to the broader population or candidate pool, this percentage actually represents a relative underrepresentation of women when we consider gender representation in doctoral degrees granted.

The 33\% representation rate of women across Canadian archaeology faculty is comparable to the 35\% figure Goldstein cites for U.S. faculty (2018). It is a vast increase from the 19891990 Canadian data cited by Kelley and Hill (1994), in which women constituted only $20 \%$ of junior faculty. Nonetheless, the archaeology professoriate is top-heavy: assistant professors comprise only $22 \%$ of faculty members, and tenured men constitute a full $55 \%$ of all faculty members $(n=71)$. This situation is perhaps an 

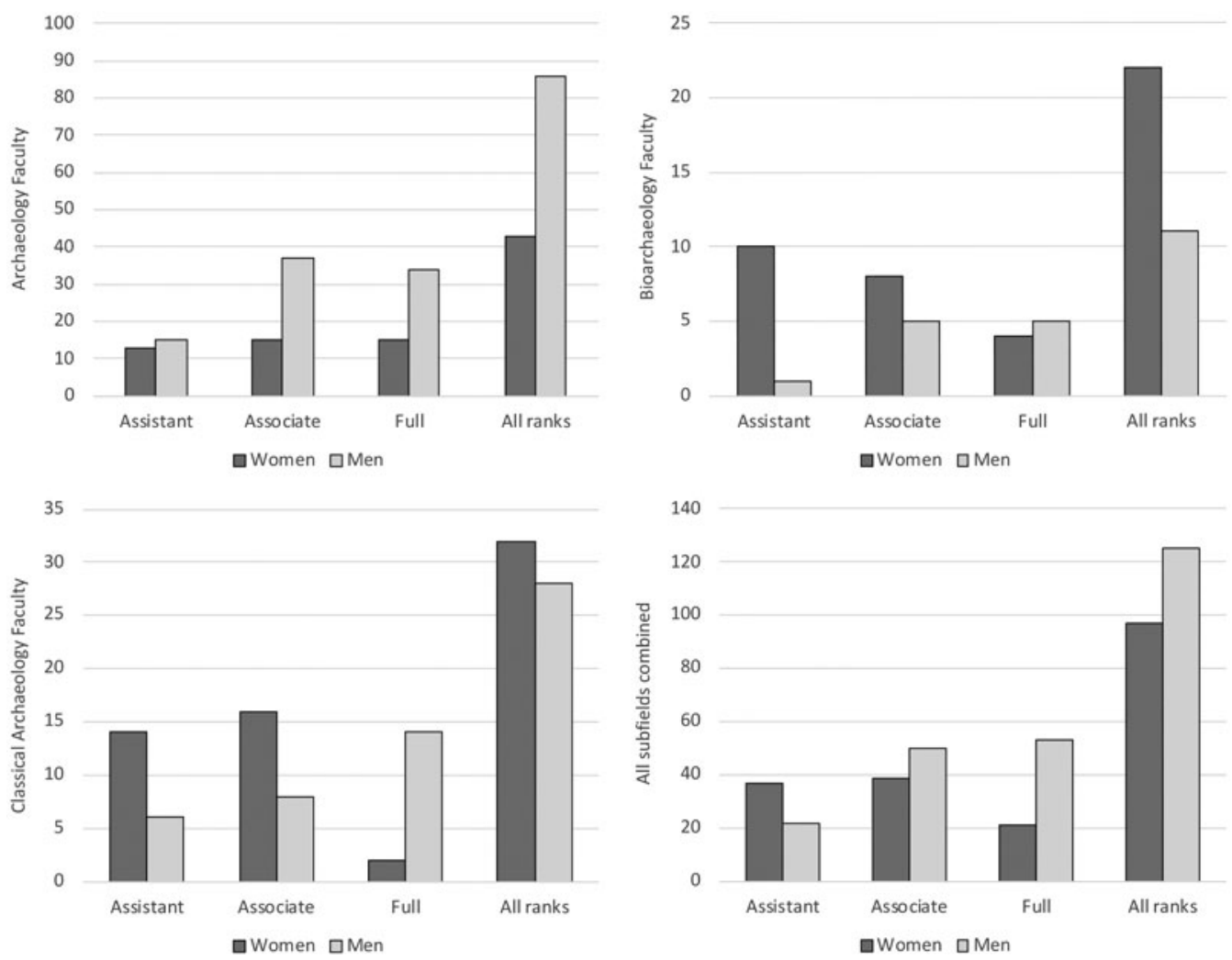

Figure 2. Charts showing the numbers and relative proportions of men and women in tenure-track and tenured faculty positions by rank within archaeology, bioarchaeology, classical archaeology, and all subfields combined.

unintended consequence of the end of mandatory retirement in Canada. The increasing adjunctification crisis in academia leads us to question whether those tenure-track positions will be replaced. This factor-and the gender ratio of those hired-will affect when and if parity is reached.

Because men are overrepresented in graduate and especially doctorate-granting U.S. institutions within archaeology (Goldstein et al. 2018; Speakman, Hadden, Colvin, Cramb, Jones, Kling, et al. 2018), we also subdivided universities by research intensity. Our criteria included membership in the U15 Group of Canadian Research Universities (roughly equivalent to R-1 status in the United States) and the presence of a $\mathrm{PhD}$ program. For this and remaining analyses, we examined only archaeologists and excluded classical archaeologists and bioarchaeologists. We found no gendered difference in universities that fit either U15 membership or $\mathrm{PhD}$ program criteria: $49 \%$ of women $(n=21)$ and $51 \%$ of men $(n=44)$ faculty members are located in U15 universities, and $67 \%$ of both women $(n=29)$ and men $(n=58)$ are in $\mathrm{PhD}$-granting departments. Consequently, women are equally represented at researchintensive Canadian institutions.

\section{The Archaeology Pipeline: Doctoral to Faculty}

The demographic data presented here provide significant insight into archaeology's "pipeline" today. The pipeline model, originally developed for STEM fields, postulated that increasing the number of women interested in science would eventually (as they traveled inside the pipe) result in greater gender parity in scientific careers. This model was quite quickly debunked because scholars realized that the pipeline was "leaky": women do not progress through the ranks in the same proportions as men, and instead, they drop or "leak" out of STEM fields at various career stages (Schiebinger 1999). 
As an analytical tool to guide data collection and interpretation, the pipeline concept encourages us to follow people over their career trajectory and identify the specific moments at which pathway changes occur, particularly for women and other underrepresented groups. It is important to recognize that movements within the pipeline are varied and complex, often constituting more than "leaking." For example, they can propel you forward, backward, stall you in place, or push you out - a more forceful motion than what leaking implies. Understanding the multitudinous factors that promote different movements within the pipeline is vital. But the pipeline concept alone cannot account for contextual differences in motivations and experiences between individuals, nor does it address the fact that many career decisions are made in early adulthood, simultaneously with many other family and personal decisions (Cannady et al. 2014:446-447). As an initial critical metaphor, however, the pipeline may help frame research questions for later investigation using survey, interview, and ethnographic methods (for recent examples, see Heath-Stout 2019; Jalbert 2019).

The discipline of archaeology should be conceptualized as one pipeline that has multiple, intersecting chambers allowing for fluid movement. Although pathways to academia are present, equally present (and more heavily populated) are pathways to private industry, variably called contract archaeology, consulting, heritage management, or cultural resources management (CRM). Due to length restrictions, a closer examination of CRM professionals is outside the scope of this article, but it is treated in Jalbert's dissertation (2019). It is worth noting movement between the academic and private sectors for some individuals during their career. Although academia may not be the career goal for many archaeologists trained within the university system, an underrepresentation of women among archaeology faculty may deter women from pursuing archaeological careers in all sectors. Consequently, it is crucial that we understand academic archaeology's demographics.

Comparing doctoral and faculty datasets, it is clear that women archaeologists disproportionately exit academia at this juncture. Women have earned $66 \%$ of all doctoral degrees in archaeology in the last five years and $64 \%$ over the last 10 years, yet they represent only $46 \%$ of assistant professors $(n=13)$. The mean, median, and mode for degree year of assistant professors are 2010, 2012, and 2013, respectively; five of the 29 assistant professors in Canada received their degrees before 2007 , and two after 2016. Consequently, the 2007-2016 doctoral degrees data provide the closest approximation of market availability when those assistant professors were hired. Given their representation in the $\mathrm{PhD}$ recipient pool for both the last five and 10 years, we would have expected 18 women to be hired using either period's proportions. A $\chi^{2}$ test of these values revealed a statistically significant $p$ value of 0.049 ( $\chi^{2}$ [1] value of 3.889). That is, women are hired in Canada in proportions lower than their presence in the $\mathrm{PhD}$ recipient pool. From doctoral degree to assistant professor, there is a nearly $20 \%$ drop in the representation of women. By themselves, these data do not address whether this underrepresentation is due to differing career goals, implicit bias in hiring, or other factors altogether.

Canadian-produced $\mathrm{PhDs}$ are not the only candidates for those positions. Only 48\% ( $n=$ 62) of faculty members received their doctorates in Canada, with 36\% $(n=47)$ receiving their training in the United States and $16 \%(n=20)$ in Europe. These numbers might lead to the hypothesis that the majority of men among tenure-track assistant professors in Canada is a reflection of a more male-dominated international candidate pool. We can reject this idea, however, given that men at the assistant professor level were actually more likely to have received their $\mathrm{PhD}$ in Canada (11 out of 15 men vs. 4 out of 13 women; $\chi^{2}$ test $p$ value of 0.024 ). Only $14 \%$ of tenure-track positions are currently filled by women who were trained in Canada. Looking at the dataset another way, and examining all professorial ranks, Canadian universities today employ 16 men and 7 women who earned their PhDs in Canada between 2003 and 2017 (Table 1). These individuals represent $36 \%$ of men and $12 \%$ of women who received their $\mathrm{PhDs}$ in Canada during this time period-that is, men who earned their degrees in Canada between 2003 and 2017 are three times more 
Table 1. Gender in PhD Recipients in Canada 2003-2017 and Tenure-Track Faculty in Canada and the United States in 2019.

\begin{tabular}{lcccc}
\hline & $\begin{array}{c}2003-2017 \\
\text { Archaeology PhDs in } \\
\text { Canada }\end{array}$ & $\begin{array}{c}\text { 2003-2017 PhDs Employed } \\
\text { in Canadian Tenure-Track } \\
\text { Positions }\end{array}$ & $\begin{array}{c}\text { 2003-2017 PhDs Employed in } \\
\text { US Tenure-Track Positions }\end{array}$ & $\begin{array}{c}\text { Percentage of 2003-2017 } \\
\text { PhDs Employed in North } \\
\text { America }\end{array}$ \\
\hline Women & 57 & 7 & 10 & $30 \%$ \\
Men & 45 & 16 & 2 & $40 \%$ \\
\hline
\end{tabular}

likely to occupy faculty positions in Canada today. Women with Canadian PhDs have been hired into tenure-track positions in Canada at rates statistically lower than men; a $\chi^{2}$ test for all Canadian professors who earned $\mathrm{PhDs}$ between 2003 and 2017 produced a highly significant $\chi^{2}(1)$ value of $6.369(p=0.012)$. The very low numbers of women with Canadian $\mathrm{PhDs}$ hired at Canadian institutions are even more concerning because Canadian law dictates that universities prioritize the hiring of Canadian citizens over international scholars, given equally qualified candidates.

So, where are these women going? We might suspect that women are choosing to enter museums, CRM, or other industries in a greater proportion. Although tracking and quantifying individuals in these sectors is difficult (see Everill 2009; Zeder 1997a; Zorzin 2010), Jalbert's (2019:145) recent analysis of available CRM permit data demonstrated that women are far less likely to be the permit-holder / principal investigator. Although this data point is limited to the senior level and does not provide insight into archaeologists who enter CRM as field/lab technicians or staff, it does suggest that women who earn $\mathrm{PhDs}$ are not more likely to enter the private sector as senior archaeologists. Alternatively, they may be leaving archaeology entirely, perhaps a consequence of the "chilly climate" factors that will be discussed in further detail below.

We might also speculate that women are more successful in securing academic positions elsewhere, perhaps in the United States' larger job market. To address this question, we conducted degree institution searches in the AAA Anthro Guide for each of the Canadian PhD-granting universities, limiting our search to archaeology faculty in the United States and to 2003-2017 doctorate recipients. We recorded a total of 12 archaeology faculty members with Canadian
PhDs who were hired at U.S. institutions, including five who are currently at the assistant level, six at associate, and one at full. Of these, 10 are women $(83 \%)$, and two are men (17\%)-gender proportions nearly reversed from those of Canadian hires (Table 1). The United States therefore hires women with Canadian PhDs in greater numbers than their proportion among $\mathrm{PhD}$ recipients in Canada, although the difference is not statistically significant $\left(\chi^{2}[1]=3.086, p=0.079\right)$.

Therefore, some women who earned $\mathrm{PhDs}$ in Canada did not "leak" out of archaeology entirely. Instead, they found academic positions in the United States, many at R1 institutions. In fact, these women with Canadian PhDs seem to be outperforming the broader pool of women candidates in U.S. tenure-track searches (Speakman, Hadden, Colvin, Cramb, Jones, Kling, et al. 2018). These statistics may reflect an inability to retain top talent within Canada, although the numbers are small.

Putting the datasets for U.S. and Canadian hiring together, $40 \%$ of the men and $30 \%$ of the women who earned PhDs between 2003 and 2017 are currently employed in tenure-track or tenured positions somewhere in North America. Although a gender gap remains, these numbers are higher than the recent $20 \%$ figure for men and women with U.S.-produced PhDs (Speakman, Hadden, Colvin, Cramb, Jones, Kling, et al. 2018).

The faculty survey also allowed us to compare the Canadian programs that are producing successful candidates for tenure-track positions, following similar analyses in the United States (Speakman, Hadden, Colvin, Cramb, Jones, Kling, et al. 2018). Assistant professors in Canada received their $\mathrm{PhDs}$ at nine different Canadian universities, with no single institution accounting for more than three graduates, whereas three universities produced $\mathrm{PhDs}$ - no more than two each—who were hired as assistant 
professors in the United States. Although the University of Calgary, Simon Fraser University, and the University of Toronto have the largest market shares, they are also the only departments with archaeology faculty members numbering in the double digits. These data indicate a less hierarchical market share in Canada in comparison to the United States.

We cannot currently assess the presence of potential biases in the selection process because we lack evidence for applicant pools for tenuretrack positions in Canada. We also lack evidence for the number of men and women archaeologists employed in museums, although that sector is comparatively small. Finally, data are lacking on the men and women employed in adjunct and lecturer positions within academia and non-permit-holding positions in CRM. However, given that women with Canadian PhDs are more successful than men on the academic job market in the United States, and given that they also appear to be underrepresented at the senior level as CRM permitholders in Canada, it seems unlikely that women who earn their $\mathrm{PhDs}$ in Canada are less likely to apply for or accept academic positions in Canada, or that they are less qualified for them.

Scholars in the United States have identified marriage and children under the age of six as accounting for the lower likelihood that women will secure a tenure-track position (Mason et al. 2013; Wolfinger et al. 2008). Family issues are a broad category, but they include (1) dual-career constraints limiting women's ability to accept or hold faculty positions and (2) parenting demands resulting in mothers opting for less constraining careers. We would suspect that Canada's paid parental leave and other family-friendly policies would help mitigate this, and there is no reason to believe that Canadian institutions are less likely to accommodate spouses in dual-career couples (Careless and Mizzi 2015). Moreover, within the pool of archaeologists who earned their $\mathrm{PhD}$ in Canada between 2003 and 2017, women were in fact far more likely to move internationally, often for research-intensive positions. Consequently, our current data do not support the hypothesis that academic women are significantly less mobile because of family obligations (Rosenfield and Jones 1987).
We might suspect that implicit-but likely subtle—gender bias or discrimination in hiring is partly responsible for how archaeologists in Canada move through and out of the pipeline at this point, as has been argued for the United States (e.g., Monroe and Chiu 2010). The underrepresentation of women in faculty positions in Canada relative to their proportions among doctorates may be due to a lack of mentorship in publishing and job application processes, weaker recommendation letters, or hiring-committee bias against research topics and methods historically dominated by women-for example, lab work-based projects such as paleoethnobotany (Gero 1985, 1991; Gifford-Gonzalez 1994). Indeed, all seven women with Canadian PhDs from 2003 to 2017 who are currently employed in Canada have active fieldwork programs, whereas five of the 10 women with Canadian $\mathrm{PhDs}$ from this period hired within the United States had women-dominated laboratory specializations. Canadian institutions did hire archaeologists with specializations typically dominated by women, but those archaeologists' degrees were from abroad. Moreover, we would expect similar constraints and biases in hiring on both sides of the border, and our current data do not explain why women would fare less well on the Canadian job market than in the United States.

The data presented here suggest that Canadian tenure-track search committees in upcoming years should expect candidate pools that are overwhelmingly made up of women. For those of us in academic departments, this is a crucial consideration, as a goal of parity (a 50-50 ratio in archaeology faculty) has the potential to result in bias against women and contribute to movement in, or leaking out of, the pipeline at this point. Therefore, it cannot be overstated that target hiring ratios should be representative of candidate pools and not those of the general population.

Unfortunately, we lack historical data on the professoriate that would allow us to assess gendered differences in retention, tenure, and/or promotion. The mean $\mathrm{PhD}$ year for women at the associate professor level, however, is 1997, compared to 2000 for men, which suggests that there is not an extremely large difference in how 
Table 2. Major Program Application and Award Data as Provided by SSHRC.

\begin{tabular}{|c|c|c|c|c|c|}
\hline & & & $\begin{array}{l}\text { Doctoral Awards } \\
\text { (all combined) }\end{array}$ & $\begin{array}{l}\text { Postdoctoral Awards } \\
\text { (all combined) }\end{array}$ & $\begin{array}{l}\text { Standard Research / } \\
\text { Insight Grants }\end{array}$ \\
\hline \multirow[t]{6}{*}{ 2003-2007 } & \multirow[t]{3}{*}{ Women } & Applications & 79 & 26 & 72 \\
\hline & & Awards & 40 & 8 & 20 \\
\hline & & Success Rate & $50.6 \%$ & $30.8 \%$ & $27.8 \%$ \\
\hline & \multirow[t]{3}{*}{ Men } & Applications & 47 & 27 & 141 \\
\hline & & Awards & 29 & 11 & 49 \\
\hline & & Success Rate & $61.7 \%$ & $40.7 \%$ & $34.8 \%$ \\
\hline \multirow[t]{6}{*}{ 2008-2012 } & \multirow[t]{3}{*}{ Women } & Applications & 101 & 42 & 95 \\
\hline & & Awards & 54 & 8 & 26 \\
\hline & & Success Rate & $53.5 \%$ & $19.0 \%$ & $27.4 \%$ \\
\hline & \multirow[t]{3}{*}{ Men } & Applications & 42 & 33 & 118 \\
\hline & & Awards & 24 & 8 & 37 \\
\hline & & Success Rate & $57.1 \%$ & $24.2 \%$ & $31.4 \%$ \\
\hline \multirow[t]{6}{*}{ 2013-2017 } & \multirow[t]{3}{*}{ Women } & Applications & 113 & 55 & 66 \\
\hline & & Awards & 46 & 11 & 18 \\
\hline & & Success Rate & $40.7 \%$ & $20.0 \%$ & $27.3 \%$ \\
\hline & \multirow[t]{3}{*}{ Men } & Applications & 56 & 41 & 139 \\
\hline & & Awards & 26 & 13 & 35 \\
\hline & & Success Rate & $46.4 \%$ & $31.7 \%$ & $25.2 \%$ \\
\hline
\end{tabular}

quickly women are promoted and receive tenure. Nonetheless, we do not know when those individuals were hired, nor how many were denied tenure.

\section{SSHRC Grants Data}

Given that grant funding is key to academic success, and because archaeology grant submission rates have recently received American scholarly attention (see Goldstein et al. 2018), we requested data on applications and awards submitted and received by men and women for the discipline of archaeology from SSHRC. Doctoral, postdoctoral, and senior research competition data were available for the last 15 years, binned into five-year increments (Table 2).

SSHRC combined all doctoral and all postdoctoral competitions to ensure anonymity. Doctoral awards include the SSHRC Doctoral Fellowships, the Joseph-Armand Bombardier Canada Graduate Scholarships (CGS), and the Vanier Canada Graduate Scholarships. Postdoctoral competitions include the SSHRC and the Banting Postdoctoral Fellowships. The SSHRC Doctoral, Vanier Canada, and Banting Postdoctoral datasets include students put forward by their universities after a preliminary selection process. We do not have any way to assess gendered differences in success rates at the internal competition level. SSHRC was unable to send data on the prestigious Canada Research Chairs because of the limited application numbers, but searches of their online awards database revealed five men (63\%) and three women (38\%) who have held chairs in the last 15 years-figures that are representative of the proportions of men and women in the professoriate overall.

\section{SSHRC Archaeology Application Rates}

The "leaks" in archaeology's pipeline in Canada are also visible in the SSHRC application numbers. Between 2003 and 2017, women consistently formed $60 \%-70 \%$ of doctoral applicants, $50 \%-60 \%$ of postdoctoral applicants, and $30 \%-40 \%$ of senior research applicants in archaeology (Figure 3). Women consistently submitted approximately twice as many doctoral applications, whereas men submitted nearly twice as many senior-level applications.

These numbers are consistent with the doctorate and assistant professor demographic data discussed earlier. Given that SSHRC doctoral applications are generally submitted early in graduate school, some applications in one fiveyear period likely resulted in doctorates awarded in the next. Consequently, the 12 women (57\%) and nine men $(43 \%)$ who earned their doctorates 

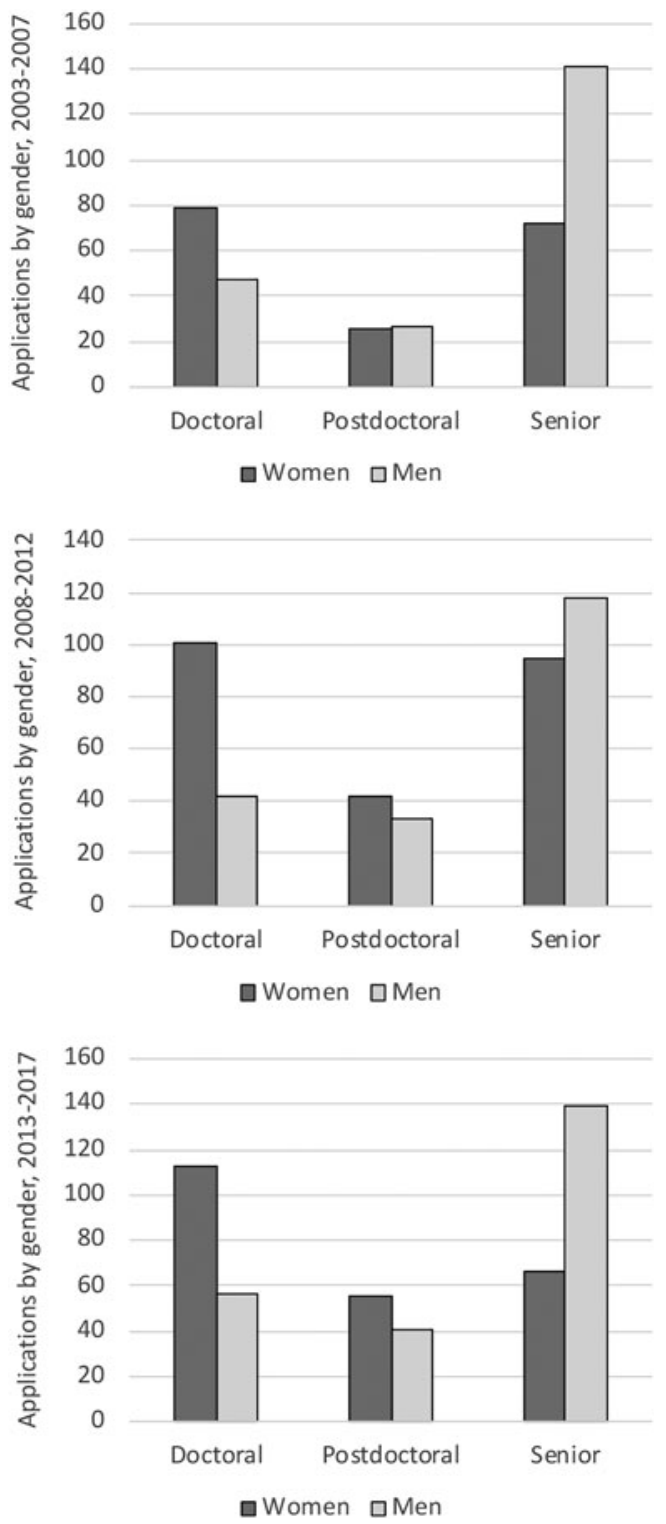

Figure 3. SSHRC applications numbers at doctoral, postdoctoral, and senior research levels by gender (20032007, 2008-2012, and 2013-2017).

between academic years 2007-2008 and 20112012 likely submitted some of the 79 women's (63\%) and 47 men's (37\%) applications between 2003 and 2007. Similarly, the 30 women $(67 \%)$ and 15 men (33\%) who earned their PhDs between 2012-2013 and 2016-2017 were likely behind some of the 101 women's applications (71\%) and 42 men's applications (29\%) between
2008 and 2012. It is possible that there are gendered differences in the number of times individuals applied on average. Goldstein and colleagues (2018) speculated that men are less likely to be discouraged by negative reviewer feedback and more likely to reapply. Nonetheless, these numbers track comparatively well, with women relatively equally represented among doctoral fellowship applicants and doctoral degree recipients. These data do not support the hypothesis that women drop out of graduate school more often than men, which suggests an improvement in the retention of women in archaeology graduate programs in Canada since Kelley and Hill's publication (2019).

Comparing SSHRC data for doctoral and senior levels reveals a decrease in women's applications from $60 \%-70 \%$ to only $30 \%-40 \%-$ consequently, a significant "leak" following doctoral degree programs and before senior-level projects. Women's representation as senior research grant applicants in archaeology neatly corresponds to their representation among all faculty $(33 \%)$ in this study's survey. Moreover, cross-referencing faculty with the searchable SSHRC database showed that men and women archaeology faculty members currently employed at Canadian institutions are equally likely to have received funding during the 15 -year study period (Table 3 ). The decrease in proposals by women across the course of their academic career is therefore indicative of women exiting the academic pathway rather than women not requesting funding. It is possible that proportionately more women move into other pathways within archaeology-for example, the private sectorafter earning their doctorate degree, although the movement of these groups is currently difficult to track.

The same trend of declining grant submissions by women is seen at each stage in each five-year period, indicating no improvements in the last 15 years. In fact, the last five years was the lowest for women's representation as senior research applicants. Women submitted $63 \%$ of doctoral applications in archaeology between 2003 and 2007, but still only comprised 32\% of senior-level submissions in the 2013-2017 period. We might not have expected women to reach parity by the most recent five-year period 
Table 3. SSHRC Funding Rates for Current Archaeology Faculty Members in Canada, Grant Periods 2003-2017.

\begin{tabular}{llrr}
\hline & & Funded & Not Funded \\
\hline Assistant & Women & $8(62 \%)$ & $5(38 \%)$ \\
& Men & $9(60 \%)$ & $6(40 \%)$ \\
Associate & Women & $10(67 \%)$ & $5(33 \%)$ \\
& Men & $25(68 \%)$ & $12(32 \%)$ \\
Full & Women & $13(87 \%)$ & $2(13 \%)$ \\
& Men & $26(76 \%)$ & $8(24 \%)$ \\
\hline
\end{tabular}
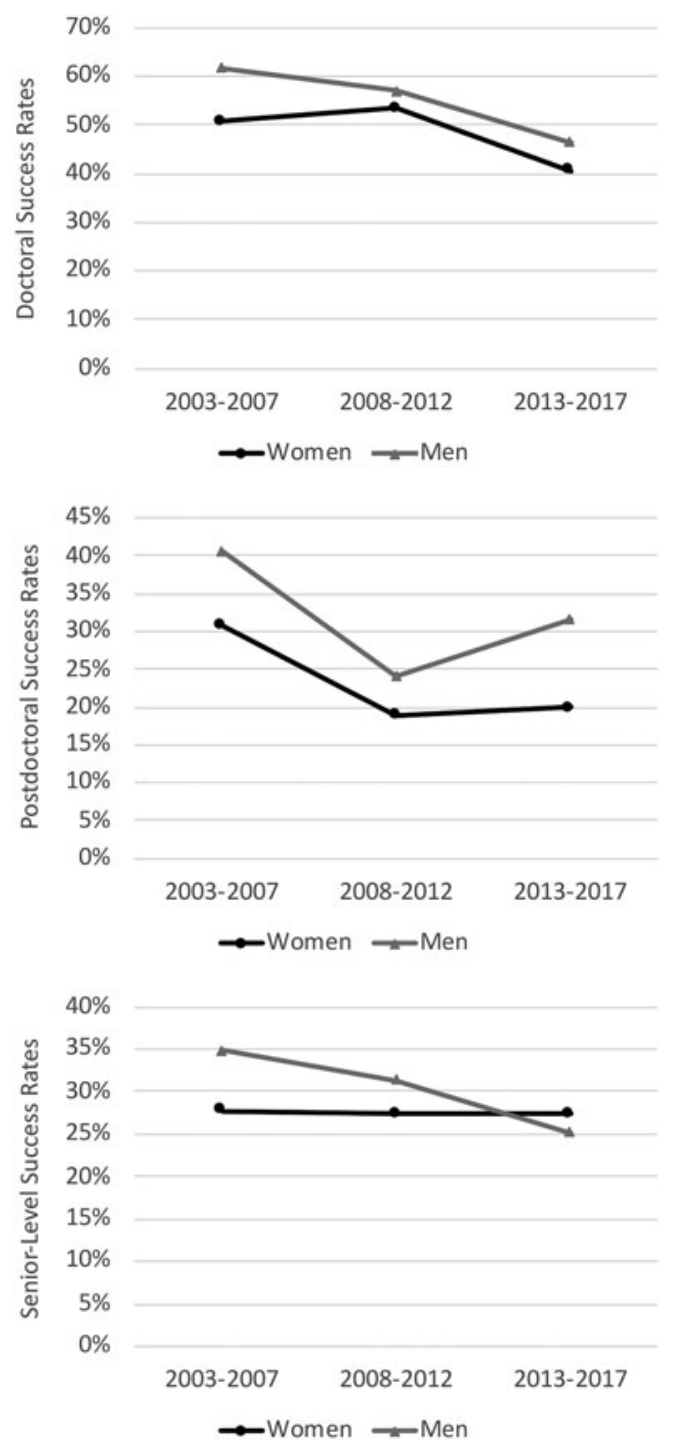

Figure 4. Success rates of men and women in doctoral, postdoctoral, and senior-level SSHRC competitions (2003-2007, 2008-2012, and 2013-2017). given the low post-recession hiring rates that are visible in the lower number of assistant professors compared to associate and full professors (Figure 2). Nonetheless, we would have expected some movement toward parity assuming that women are equally well trained, equally pursue academic jobs, and are not targets of systemic bias in hiring.

Comparing SSHRC grant application data to Goldstein and colleagues' (2018) recent analysis of NSF grants (FY2004, 2008, and 2013) suggests that the Canadian archaeology pipeline is even leakier. Whereas at the senior-level Goldstein and colleagues (2018) similarly report nearly twice as many applications by men, at the doctoral level, U.S. applications reflect relative parity, with the 2013 data reporting the greatest representation of women (59\%). Consequently, although the endpoints are similar in the United States and Canada, more women enter as doctoral students in Canada and are affected by processes within the pipeline.

\section{SSHRC Archaeology Success Rates}

Success rates in SSHRC archaeology grant competitions were approximately $25 \%-35 \%$ at the senior level, $20 \%-40 \%$ at the postdoctoral level, and $40 \%-60 \%$ at the doctoral level. The doctoral-level rates include only applications that were preselected by universities after departmental and college levels of competition, and for this reason, we cannot compare success rates to those of other countries. The senior-level success rates, however, are comparable to those reported for the United States (Goldstein et al. 2018), although it is worth recalling that much of the period studied here reflects the budgetary constraints on research implemented by Prime Minister Stephen Harper (2006-2015).

Analyzing the success rates for all archaeology grant competitions by gender (Figure 4) reveals a slightly higher rate for applications submitted by men consistently across time and across levels, with the single exception of the most recent period, in which senior women were $2.1 \%$ more successful. These differences are slight; men were $3.6 \%-11.7 \%$ more successful than women in all other instances, with an average of $7.3 \%$. The difference appears to be greater in the doctoral and postdoctoral 
Table 4. Application and Award Data Provided by SSHRC for Other Funding Codes for Archaeology.

\begin{tabular}{|c|c|c|c|}
\hline & & Women & Men \\
\hline \multirow[t]{3}{*}{ Northern Research Development Program (2003-2007) } & Applications & 12 & 7 \\
\hline & Awards & 8 & 4 \\
\hline & Success Rate & $66.6 \%$ & $57.1 \%$ \\
\hline \multirow[t]{3}{*}{ Research Development Initiatives (2000-2010) } & Applications & 9 & 16 \\
\hline & Awards & 4 & 5 \\
\hline & Success Rate & $44.4 \%$ & $31.3 \%$ \\
\hline \multirow[t]{3}{*}{ CURA (1999-2009) } & Applications & 4 & 13 \\
\hline & Awards & 1 & 4 \\
\hline & Success Rate & $25.0 \%$ & $30.8 \%$ \\
\hline \multirow[t]{3}{*}{ Major Collaborative Research Initiatives Program (2000-2011) } & Applications & 0 & 11 \\
\hline & Awards & 0 & 4 \\
\hline & Success Rate & $0.0 \%$ & $36.4 \%$ \\
\hline \multirow[t]{3}{*}{ Aboriginal Research $(2004,2007,2009)$} & Applications & 1 & 5 \\
\hline & Awards & 0 & 2 \\
\hline & Success Rate & $0.0 \%$ & $40.0 \%$ \\
\hline \multirow[t]{3}{*}{ International Opportunities Fund (2007-2009) } & Applications & 1 & 5 \\
\hline & Awards & 1 & 2 \\
\hline & Success Rate & $100.0 \%$ & $40.0 \%$ \\
\hline \multirow[t]{3}{*}{ Insight Development Grant (2011-2014) } & Applications & 19 & 32 \\
\hline & Awards & 6 & 11 \\
\hline & Success Rate & $31.6 \%$ & $34.0 \%$ \\
\hline \multirow[t]{3}{*}{ Partnership Development Grant (2011-2013) } & Applications & 3 & 4 \\
\hline & Awards & 1 & 2 \\
\hline & Success Rate & $33.3 \%$ & $50.0 \%$ \\
\hline \multirow[t]{3}{*}{ Partnership Grants (2011-2014) } & Applications & 2 & 8 \\
\hline & Awards & 0 & 2 \\
\hline & Success Rate & $0.0 \%$ & $25.0 \%$ \\
\hline
\end{tabular}

competitions. According to $\chi^{2}$ tests, these trends do not rise to statistical significance. For example, a $\chi^{2}$ test for the doctoral competition statistics from 2003 to 2007 revealed a $p$ value of 0.227 . Yet, it would be misleading to discount the practical differences that are consistent across years and researcher levels.

Jalbert (2019) further revealed that women were also less successful in other senior-level SSHRC funding programs. These programs include a number of grants aimed at research development and collaboration (Jalbert 2019; Table 4). Women generally submitted fewer applications than men-only representing an average of $34 \%$ of applicants-and no grants were awarded to women in three out of the nine programs. ${ }^{1}$ Jalbert (2019:143) concluded that although the number of applications submitted by women is proportionate to their representation in faculty positions, she also considers how the formation of academic networking relationships between men and women might impact both application and success rates to funding programs such as those offered by SSHRC (see Husu 2001; Nokkala et al. 2016).

Considering grant application and success rates in their totality, it is possible that reviewer bias is at play, given that applicants are not anonymized (although reviewers are), or that other aspects of gendered dynamics might be producing these differences. For example, studies have found that science faculty members are more willing to mentor men (Moss-Racusin et al. 2012), and women studying anthropology and archaeology are more likely to suffer from marginalization, discrimination, gender harassment, and microaggressions (Clancy et al. 2014; Meyers et al. 2018; Nelson et al. 2017; see also Jalbert [2019] and Hodgetts et al. [2020] for Canadian archaeology). Lower success rates of women could reflect training and mentoring deficiencies, specifically in grant writing. Goldstein and colleagues (2018:369) identified a positive correlation between the gender of 
the adviser and that of the student, but they did not have the data to assess whether women were more likely to be successful if they had women as advisers-as might be expected given that gender and sexual harassment is far more common when women study with men (Clancy et al. 2014).

Gendered language and gendered research topics may also contribute to the discrepancy. Business scholars (Kolev et al. 2019) have found a gendered disparity in scores in blinded review processes that remains even after controlling for applicant publication history and reviewer demographics. They found, however, that the disparity disappears when controlling for word choice. In particular, men tend to use words that are found across all proposals (such as "drug," "detection," "target," "bacteria," and "therapy"), whereas women tend to use words that vary significantly in usage across proposals (such as " children," "vaccination," "contraceptive," and "community"). Although researchers call these "broad" and "narrow" words, respectively, it is clear that these words reflect research topics and subjects that are traditionally gendered. Consequently, we might consider the possibility of bias in grant evaluation against those research topics and methods that are typically feminine coded, as we suggested might be possible for the job market.

We were not given access to individual SSHRC application scoring data, so we were unable to assess the relative strength of applicant pools by gender and evaluate reviewer bias. Similar analyses of CIHR data (Tamblyn et al. 2018) suggest that it would be possible and fruitful for SSHRC-funded archaeology grants.

\section{A Leaky Pipeline and Chilly Climate}

The data presented here indicate that a great deal of progress has been made since the 1980s. Women are represented at substantially higher rates since Kelley and Hill's publication (2019). They estimated that between $28 \%$ and $33 \%$ of Canadian archaeology graduate students were women, and as discussed previously, $20 \%$ of assistant professors were women. Today, women earn two-thirds of all archaeology doctorates, and they constitute $46 \%$ of junior faculty.
There are still, however, twice as many men among archaeology faculty.

Perhaps more importantly, the data presented here demonstrate that a drop of approximately $20 \%$ in women's representation exists between the receipt of a doctoral degree and the appointment to a tenure-track position. Whereas most of the men hired to tenure-track positions received their $\mathrm{PhDs}$ at domestic institutions, most of the women hired in Canada were trained internationally. Therefore, the underrepresentation of Canadian $\mathrm{PhD}$ women is even more marked within Canadian academic positions. Women who earned their $\mathrm{PhDs}$ in Canada between 2003 and 2017 were hired in Canada at significantly lower rates (and in the United States, they were hired at higher rates) compared to their proportions within $\mathrm{PhD}$ cohorts, which suggests the possibility of systemic, implicit gender bias in the Canadian hiring process. This is of significant concern for those of us training women graduate students in Canada who are interested in pursuing academic careers. We might hypothesize that the gains in women's representation have only occurred because the archaeological pipeline begins with a contingent overwhelmingly dominated by women-that is, the $33 \%$ of women's representation in the archaeology professoriate today exists at the cost of the many women who leave after significant personal and professional investment.

Many factors likely contribute to the poor retention of women in archaeology's pipeline in Canada. This study points to (1) slightly lower success rates for women in the past 15 years in grant competitions, perhaps due to differences in mentoring and/or the devaluing of typically women-dominated or feminine-coded research topics and methods; (2) significantly lower success rates for women (especially for Canadian-trained women) in tenure-track job searches in Canada over the past 15 years, possibly due to systemic bias in hiring; and (3) low rates of tenure-track hiring in archaeology in the past decade, when women have constituted roughly two-thirds of the candidate pool, which coincides with the end of mandatory retirement in Canada. The relative importance of those factors and their root causes is unclear, and as Smith suggests, 
The gaps in institutional knowledge on the dynamics at play-leaky pipelines or impermeable glass ceilings-suggests the need to ask hard questions about discrimination and barriers, as well as equitable recruitment, retention, gender bias in mentoring and hiring, and the culture and climate of graduate programs [Smith 2013:6].

The findings presented in this article are consistent with U.S. statistics reported by Canadian philosopher of archaeology Alison Wylie over 25 years ago. Wylie (1993) describes this situation as a symptom of the "revolving door" (Wylie 1993:249) syndrome: despite making it through the door into the field of archaeology and earning $\mathrm{PhDs}$, women face differential rates of appointment and advancement that are not explained by their productivity. She attributes women's continued status as "second class citizens ... disproportionately clustered in the lower and more vulnerable ranks" (Wylie 1993:251) to a discriminatory work environment. Wylie (1993:67; see also Chilly Collective 1995) drew on the concept of a "chilly climate" in academia, which was formulated by Sandler and Hall (Hall and Sandler 1982, 1984; Sandler 1986) to refer to subtle, nondiscursive, and informal practices that stereotype, exclude, and devalue women. These practices, Parezo and Bender (1994:73) argued, only arise after the representation of women (or any historically excluded group) reaches a level that is considered threatening to the majority-somewhere between $20 \%$ and $35 \%$.

Although "chilly climate" is a rather broad concept, Wylie (1993) identified several specific factors: (1) gender stereotyping, resulting in heavier service and teaching demands; (2) devaluing of research accomplishments, resulting in women being less competitive in job searches, and if hired, lower salaries and allocation of institutional resources; and (3) sexual harassment and assault, resulting in women leaving the discipline. To this list, we might add (4) a work environment that is not family-friendly.

Wylie explains that women are often assigned heavier service loads and other stereotypical "housekeeping" tasks early in their careers, leaving them with less time for research and having negative consequences for advancement. Interviews by Goldstein and colleagues (2018) confirm that academic women in the United States commonly feel overextended due to service burdens and "hidden labor" (Goldstein et al. 2018:374-475). Women who had not applied for NSF grants cited heavy service burdens twice as often as those who had applied (Goldstein et al. 2018). As discussed earlier, our faculty survey did not find a large difference in how quickly women faculty members are promoted to associate professor, which suggests that if women in Canada do have heavier service and "hidden labor" burdens, it is not affecting the speed with which they are tenured. Nonetheless, we lack data on tenure rates and gender.

Women's research accomplishments are often devalued in academia, and women's actual achievements are often compared with men's potential achievements in hiring decisions (Sandberg 2013; Wylie 2013), which possibly causes discrepancy in tenure-track hiring. Wylie (2013) mentions gendered discrepancies in pay, but inequities in laboratory size and start-up packages might also represent gendered differences in institutional resource allocation. These factors likely contribute to career dissatisfaction in academia and, thus, institutions' inability to retain women. We lack data that speak directly to such devaluing, although the lower success rates of women in grants and tenure-track searches in Canada is consistent with it. Statistics Canada data suggest that pay discrepancies in Canadian academia overall are small but persistent, despite salary adjustments made recently at a number of universities (Statistics Canada 2018).

Wylie (1993) briefly mentions that women are sexualized and subject to significant sexual harassment and assault, which reinforce the notion that women do not belong and lower their workplace satisfaction. This subject has received far more attention in recent years in archaeology and anthropology broadly (Clancy et al. 2014; Meyers et al. 2018; Nelson et al. 2017; Radde 2018; VanDerwarker et al. 2018). Using qualitative interview data, Nelson and colleagues (2017) link discrimination, sexual harassment, and safety issues with a lack of access to research opportunities and resources, and ultimately to 
career disruptions, especially for women. The subject was also the focus of the highly visible \#MeToo in archaeology session at the 2019 Annual Meeting of the Society for American Archaeology (SAA). The SAA implemented policies on sexual harassment in 2015 and antiharassment in 2018, and after a public scandal involving the attendance of known sexual predator David Yesner at the 2019 meeting, it established the Task Force on Sexual and AntiHarassment Policies and Procedures and the Meeting Safety Committee.

The CAA also formed a committee to draft and propose a policy on member safety, sexual harassment and assault, member code of conduct, and qualifications for membership. The 2019 survey of the CAA's Working Group on Equity and Diversity (Hodgetts et al. 2020) revealed that $80 \%$ of women and $75 \%$ of men had negative experiences (harassment, physical violence, sexual violence) a few times or many times. Students and young archaeologists reported negative experiences in all categories at higher rates. Women were far more likely to suffer from gender-based discrimination, verbal harassment, sexual touching, and sexual violence, whereas men were more likely to suffer from age-, seniority-, or ethnicity-based discrimination, exploitation, and physical violence. Men in positions of authority were identified as the vast majority of perpetrators in all categories. Verbal harassment, physical violence, and exploitation were more frequently reported for CRM, whereas individuals reporting sexual violence were more than three times as likely to have been in academic roles at the time of the violence (73.7\% vs. $21.1 \%$ ). These findings are alarming and point to the need for additional research to investigate how these negative experiences result in disruptions to career trajectories in Canadian archaeology.

Finally, Kelley and Hill (2019) found that some women (but no men) who withdrew from the University of Calgary's graduate program cited family and childcare reasons. This pattern existed despite the fact that fewer women enrolled were parents (10\% vs. $25 \%$ ). Interestingly, Goldstein and colleagues (2018) found that although nearly all of the 36 faculty women they interviewed mentioned the challenge of balancing family responsibilities and fieldwork, most indicated that they were able to do so thanks to supportive partners and "creative childcare" (Goldstein et al. 2018:376-377). Perhaps pessimism regarding the feasibility of having both a family and an active research project was one of the factors that influenced whether women exited or shifted career pathways in the pipeline. Surveying anthropologists in all subfields of anthropology, Lynn and colleagues (2018) found that women reported a more negative impact of their career on family planning and ranked their work-life balance more negatively. Women were also less likely have to conducted fieldwork after having children. Similarly, Ceci and Williams (2011) argued that women's underrepresentation in math-intensive science disciplines is due not to discrimination or bias, but rather to career/family balance issues and career preferences-both free and constrained. Accordingly, they suggest the implementation of a parttime tenure-track option for parents that could transition to full-time later in careers when family needs are less extreme.

A number of other policy outcome recommendations have been suggested within academia in order to address work/family balance issues that disproportionately affect women (Mason et al. 2013). Some of these are already present in Canada, including extended paid parental leave ( present at the federal level since 2000) and subsidized childcare (present in some Canadian provinces). Formal spousal accommodation programs, important since women are disproportionately partnered with other academics, are present in some Canadian institutions. For example, among the Mesoamerican archaeologists surveyed by Ford and Hundt (1994:150), 60\% of women but only $22 \%$ of men were in dual-career couples.

There is also current movement across North America to provide fieldwork-specific financial support for archaeologists with familiessupport that is essential for women, who often take on more childcare responsibilities. National Geographic added a supplement for women and dependent care in 2017 that enables women whose research is already funded by National Geographic to apply to fund additional 
professional development, training, or conferences or to pay for dependent care assistance for these and fieldwork trips. SSHRC currently allows dependent travel or care as an eligible expense only in the case of breastfeeding children or children with single parents. This does not apply to older children, even when both parents must travel. Given the centrality of fieldwork in archaeology, this limitation may be significant for academic women.

These issues now have the support of many governments, including Canada, in the form of the Athena SWAN (Scientific Women's Academic Network) program, which is designed to promote and recognize work undertaken to address gender inequality (Advance HE 2020). First launched with a focus on STEM fields in the United Kingdom more than a decade ago, it has expanded to cover nearly all disciplines and has been adopted in many countries. Canada's version, called Dimensions, was announced in May 2019, and it aims to increase equality, diversity, and inclusion more broadly, addressing gender and obstacles faced by Indigenous peoples, minority groups, LGBTQ2+ communities, and persons with disabilities (NSERC-CRSNG 2020). It is supported by SSHRC and the Canada Research Chairs (CRC) program. The latter has set gender-equity targets since 2006, and in 2019 , it added targets for persons with disabilities, Indigenous people, and visible minorities, along with even more ambitious targets for women.

Assessment of the current state of affairs is a necessary first step, and this article makes a contribution by presenting data on archaeology's pipeline and the representation of men and women within Canadian archaeology. Although we see a need for qualitative investigation of the myriad factors that influence career choices and competitiveness for grants and tenure-track positions, we might suggest a few possible ideas for paths forward: (1) additional CRC positions to improve the retention of top Canadian-trained women, (2) improved training on implicit bias for university hiring committees and SSHRC review panels, (3) the reformation of graduate programs to ensure equity in advising and learning environments that are free of abuse and sexual harassment, and (4) the expansion of dependent travel and care eligibility for SSHRC grants to children of all ages.

\section{Coda: COVID-19}

These issues may be of increased relevance and urgency given the COVID-19 pandemic, which broke out after the preparation of this article. This pandemic is laying bare the structural inequalities present in our society and will undoubtedly exacerbate current disparities within academic archaeology across North America, especially those based on gender, parenthood, and race. We suggest that attention to proximal causes for increased inequality within the discipline as a result of the pandemic is an important first step to designing solutions. We highlight four such possible causes.

First, given the current "sheltering-in-place" practices and the closure of schools and day cares-and in turn, the highly unbalanced care work between men and women-women archaeologists with children (especially young children) may see a sharp decline in their publication records in the next year or two (Minello 2020). In the first few months of the pandemic, several journal editors noticed considerable decreases in women's manuscript submissions (Flaherty 2020). Subsequent analyses of working papers confirmed many fewer first-authored articles by women in economics (Amano-Patiño et al. 2020) and medicine (Andersen et al. 2020). An intersectional survey of academics in Brazil (Staniscuaski et al. 2020) found that childless academic men reported being the least affected by the pandemic, whereas Black mothers were the most affected.

Women with and without children shoulder more domestic labor and provide more emotional labor both within the classroom (El-Alayli et al. 2018) and in the home (Erickson 2005), and many are facing decreased productivity from a sense of instability and increased anxiety caused by an uncertain future. Surveys in April and May 2020 found that women academic scientists were far more likely to (1) report an inability to concentrate on research activities and (2) describe the ways unanticipated childcare obligations have negatively impacted their research (Jung 2020; Myers et al. 2020). 
Second, the pandemic may be particularly difficult for archaeologists given that fieldwork is currently untenable for most field sites. For earlycareer scholars with active fieldwork programs, delays in fieldwork might push women graduate students out of graduate school or the academic candidate pool and decrease the likelihood that women faculty members are granted tenure. Given that dependent care responsibilities are greater for women on average, a return to fieldwork might be challenging for many women for a longer period of time compared to their male colleagues.

Third, many universities are now offering tenure clock extensions for COVID-related delays, but previous research indicates that such extensions tend to widen the gender gap in tenure. Men who took parental leave used the extra year to publish research, whereas women did not (Antecol et al. 2018). Like Malisch and colleagues (2020), we are concerned that gender-neutral COVID-19 extensions will similarly widen the gulf in productivity, tenure, and promotion between men and women in academic archaeology.

Fourth, many universities in Canada are now implementing hiring freezes, and the current candidate pool, overwhelmingly composed of women, will face even greater challenges in securing tenure-stream positions. Moreover, as Malisch and colleagues (2020:15379) explain, "In times of stress, such as pandemics, biased decision-making processes are favored, which threaten to deprioritize equity initiatives." Given that women with Canadian PhDs were being hired into tenure-track positions at lower rates before the pandemic, and given that research productivity will likely be disproportionately negatively impacted for many of these women, we are concerned that much of the progress made in gender equity in hiring in recent decades will be lost. We think that this topic merits increased scholarly attention and institutional concern.

Acknowledgments. The faculty survey was funded by Overholtzer's William Dawson chair from McGill University. She would like to acknowledge the key role of three undergraduate research assistants-Stephanie Frenette, Sophie Manfredi, and Marina Martin - who combed faculty web pages and cross-checked the SSHRC database. She would also like to thank colleagues Nicole Couture and Debra Titone for their helpful comments on a draft of the manuscript. Some of the data in this manuscript were originally presented in Jalbert's dissertation. She would like to thank her supervisors, Meghan Burchell and Lisa Rankin, and her committee members, Sonja Boon and Marica Cassis, for supporting her through the process and helping to see this work to its successful completion. An additional special thanks is due to the reviewers of an earlier version of this manuscript for connecting the authors and for providing detailed feedback that significantly improved the final article. Key datasets were provided by SSHRC Canada and Statistics Canada.

Data Availability Statement. Grants data can be requested from SSHRC Corporate Data at corporatedata@sshrc-crsh. gc.ca. Doctorates awarded can be requested from Statistics Canada at statcan.infostats-infostats.statcan@canada.ca. The faculty survey data produced for this study can be requested from the authors.

\section{Note}

1. The Partnership Development, Partnership, and Insight Development grants competition programs have run from 2011 to 2019. The data presented in Table 4 reflect the years up to the period when the data request was made to SSHRC (2014) by Jalbert (2019) for her dissertation research. All other grant competitions listed in Table 4 include the associated years when the individual grant competitions ran.

\section{References Cited}

Adamo, Shelley A.

2013 Attrition of Women in the Biological Sciences: Workload, Motherhood, and Other Explanations Revisited. BioScience 63:43-48.

Advance HE

2020 Athena Swan Charter. Electronic document, https:// www.advance-he.ac.uk/equality-charters/athena-swancharter, accessed October 20, 2020.

Amano-Patiño, Noriko, Elisa Faraglia, Chryssi Giannitsarou, and Zeina Hasna

2020 Who Is Doing New Research in the Time of COVID-19? Not the Female Economists. VoxEU, May 2. Electronic document, https://voxeu.org/article/ who-doing-new-research-time-covid-19-not-femaleeconomists, accessed November 10, 2020.

Andersen, Jens Peter, Mathias Wullum Nielsen, Nicole L. Simone, Resa E. Lewiss, and Reshma Jagsi

2020 Meta-Research: COVID-19 Medical Papers Have Fewer Women First Authors Than Expected. eLife 9: e58807. DOI:10.7554/eLife.58807.

Antecol, Heather, Kelly Bedard, and Jenna Stearns.

2018 Equal but Inequitable: Who Benefits from GenderNeutral Tenure Clock Stopping Policies? American Economic Review 108:2420-2441.

Bardolph, Dana

2014 A Critical Evaluation of Recent Gendered Publishing Trends in American Archaeology. American Antiquity 79:522-540.

Bardolph, Dana N., and Amber M. VanDerwarker

2016 Sociopolitics in Southeastern Archaeology: The Role of Gender in Scholarly Authorship. Southeastern Archaeology 36:175-193.

Beaudry, Mary C., and Jacquelyn White

1994 Cowgirls with the Blues? A Study of Women's 
Publication and the Citation of Women's Work in Historical Archaeology. In Women in Archaeology, edited by Cheryl Claassen, pp. 138-158. University of Pennsylvania Press, Philadelphia.

Bernick, Kathryn, and Sandra K. Zacharias

1995 The Status of Women in British Columbia Archaeology. Canadian Archaeological Association 19:79-96.

Cannady, Matthew A., Eric Greenwald, and Kimberly N. Harris

2014 Problematizing the STEM Pipeline Metaphor: Is the STEM Pipeline Metaphor Serving Our Students and the STEM Workforce? Science Education 98:443-460.

Careless, Erin, and Robert Mizzi

2015 Reconstructing Careers, Shifting Realities: Understanding the Difficulties Facing Trailing Spouses in Higher Education. Canadian Journal of Educational Administration and Policy 166:1-28.

CAUT (Canadian Association of University Teachers)

2018 Underrepresented and Underpaid: Diversity and Equity among Canada's Post-Secondary Education Teachers. CAUT Equity Review. CAUT, Ottawa. Electronic document, https://www.caut.ca/sites/default/files/caut_ equity_report_2018-04final.pdf, accessed November 10, 2020.

Ceci, Stephen J., and Wendy M. Williams

2011 Current Causes of Women's Underrepresentation in Science. PNAS 108:3157-3162.

Chilly Collective

1995 Breaking Anonymity: The Chilly Climate for Women Faculty. Wilfred Laurier University Press, Waterloo, Ontario, Canada.

Claassen, Cheryl (editor)

1994 Women in Archaeology. University of Pennsylvania Press, Philadelphia.

Clancy, Kathryn B. H., Robin G. Nelson, Julienne N. Rutherford, and Katie Hinde

2014 Survey of Academic Field Experiences (SAFE): Trainees Report Harassment and Assault. PLOS ONE 9(7):e102172. DOI:10.1371/journal.pone.0102172.

Drakich, Janice, and Penni Stewart

2007 Forty Years Later, How Are University Women Doing? Academic Matters: OCUFA's Journal of Higher Education, February, pp. 6-9. https://academicmatters. ca/assets/AM-Feb-2007-Issue.pdf, accessed December 17,2020

du Cros, Hilary, and Laura Jane Smith (editors)

1993 Women in Archaeology: A Feminist Critique. Occasional Papers in Archaeology Vol. 23. Canberra Department of Prehistory, Research School of Pacific Studies, Australian National University, Canberra.

El-Alayli, Amani, Ashley A. Hansen-Brown, and Michelle Cevner

2018 Dancing Backwards in High Heels: Female Professors Experience More Work Demands and Special Favor Requests, Particularly from Academically Entitled Students. Sex Roles 79:136-150.

Erickson, Rebecca J.

2005 Why Emotion Work Matters: Sex, Gender, and the Division of Household Labor. Journal of Marriage and Family 67:337-351.

Everill, Paul

2009 The Invisible Diggers: A Study of British Commerial Archaeology. Heritage Research Series 1. Oxbow Books, Oxford.

Flaherty, Colleen

2020 No Room of One's Own. Inside Higher Ed, April
21. https://www.inside highered.com/news/2020/04/21/ early-journal-submission-data-suggest-covid-19-tankingwomens-research-product ivity, accessed November 10 , 2020.

Ford, Anabel, and Anna Hundt

1994 Equity in Academia-Why the Best Men Still Win: An Examination of Women and Men in Mesoamerican Archaeology. In Equity Issues for Women in Archaeology, edited by Margaret C. Nelson, Sarah M. Nelson, and Alison Wylie, pp. 147-156. Archaeological Papers No. 5. American Anthropological Association, Washington, DC.

Fulkerson, Tiffany J., and Shannon Tushingham

2019 Who Dominates the Discourses of the Past? Gender, Occupational Affiliation, and Multivocality in North American Archaeology Publishing. American Antiquity 84:379-399.

Funk, Cary, and Kim Parker

2018 Women and Men in STEM Often at Odds over Workplace Equity. Pew Research Center: Social \& Demographic Trends, January 9. https://www.pewsocialtrends.org/2018/01/09/women-and-men-in-stem-often-atodds-over-workplace-equity/, accessed November 10 , 2020.

Gamble, Lynn H.

2020 Editor's Corner. American Antiquity 85:199-201.

Gero, Joan M.

1985 Socio-Politics and the Woman-at-Home Ideology. American Antiquity 50:342-350.

1991 Gender Divisions of Labor in the Construction of Archaeological Knowledge. In The Archaeology of Gender: Proceedings of the 22nd Annual Conference of the Archaeological Association of the University of Calgary, edited by Dale Walde and Noreen D. Willows, pp. 96-102. Archaeology Association of the University of Calgary, Alberta, Canada.

1996 Archaeological Practice and Gendered Encounters with Field Data. In Gender and Archaeology, edited by Rita P. Wright, pp. 251-280. University of Pennsylvania Press, Philadelphia.

Gifford-Gonzalez, Diane

1994 Women in Zooarchaeology. In Equity Issues for Women in Archaeology, edited by Sarah M. Nelson, Margaret C. Nelson, and Alison Wylie, pp. 157172. Archaeological Papers No. 5. American Anthropological Association, Washington, DC

Goldstein, Lynne, Barbara J. Mills, Sarah Herr, and Jo Ellen Burkholder

2018 Why Do Fewer Women Than Men Apply for Grants after Their PhDs? American Antiquity 83:367-386.

Hall, Roberta M., and Bernice R. Sandler

1982 The Classroom Climate: A Chilly One for Women? Association of American Colleges, Washington, DC.

1984 Out of the Classroom: A Chilly Campus Climate for Women? Association of American Colleges, Washington, DC.

Handly, Martin J.

1995 A Gendered Review of the Canadian Archaeological Association Bulletin (1969-1976) and the Canadian Journal of Archaeology (1977-1993): The First Twenty-Five Years. Canadian Journal of Archaeology 19:61-78.

Heath-Stout, Laura Ellen

2019 Diversity, Identity, and Oppression in the Production of Archaeological Knowledge. PhD dissertation, Department of Anthropology, Boston University, Boston. 
2020a Guest Editorial Introduction: Gender, Equity, and the Peer Review Process at the Journal of Field Archaeology. Journal of Field Archaeology 45:135-139.

2020b Who Writes about Archaeology? An Intersectional Study of Authorship in Archaeological Journals. American Antiquity 85:407-426. DOI:10.1017/aaq.2020.28.

Hodgetts, Lisa, Kisha Supernant, Natasha Lyons, and John R. Welch

2020 Broadening \#MeToo: Tracking Dynamics in Canadian Archaeology through a Survey on Equity and Diversity. Canadian Journal of Archaeology 44:20-47.

Husu, Liisa

2001 Sexism, Support and Survival in Academia: Academic Women and Hidden Discrimination in Finland. University of Helsinki, Helsinki.

Hutson, Scott R.

1998 Institutional and Gender Effects on Academic Hiring Practices. SAA Bulletin 16(4):19-21, 26.

2002 Gendered Citation Practices in American Antiquity and Other Archaeological Journals. American Antiquity 67:331-342.

Ikawa-Smith, Fumiko

2002 Gender in Japanese Prehistory. In In Pursuit of Gender: Worldwide Archaeological Approaches, edited by Sarah Milledge Nelson and Myriam Rosen-Ayalon, pp. 323-354. AltaMira Press, Lanham, Maryland.

Jalbert, Catherine

2019 Archaeology in Canada: An Analysis of Demographics and Working Conditions in the Discipline. $\mathrm{PhD}$ dissertation, Department of Archaeology, Memorial University of Newfoundland, St. John's, Newfoundland, Canada.

Jung, Heyjie

2020 COVID-19 Stay-at-Home Orders Worsen Academic Scientists' Home-Life: Women Experience More Difficulties. SSRN, July 3. DOI:10.2139/ssrn.3642732.

Kelley, Jane, and Warren Hill

1994 Relationships between Graduate Training and Placement in Canadian Archaeology. In Equity Issues for Women in Archaeology, edited by Sarah M. Nelson, Margaret C. Nelson, and Alison Wylie, pp. 47-52. Archaeological Papers No. 5. American Anthropological Association, Washington, DC.

Kolev, Julian, Yuly Fuentes-Medel, and Fiona Murray

2019 Is Blinded Review Enough? How Gendered Outcomes Arise Even under Anonymous Evaluation. National Bureau of Economic Research Working Paper 25759. DOI:10.3386/w25759.

Kramer, Carol, and Miriam Stark

1988 The Status of Women in Archaeology. Anthropology Newsletter 29(9):11-12.

Lynn, Christopher D., Michaela E. Howells, and Max J. Stein

2018 Family and the Field: Expectations of a Field-Based Research Career Affect Researcher Family Planning Decisions. PLoS ONE 13(9):e0203500. DOI:10.1371/ journal.pone.0203500.

Malisch, Jessica L., Breanna N. Harris, Shanen M. Sherrer, Kristy A. Lewis, Stephanie L. Shepherd, Pumtiwitt C. McCarthy, Jessica L. Spott, Elizabeth P. Karam, Naima Moustaid-Moussa, Jessica McCrory Calarco, Latha Ramalingam, Amelia E. Talley, Jaclyn E. CañasCarrell, Karin Ardon-Dryer, Dana A. Weiser, Ximena E. Bernal, and Jennifer Deitloff

2020 Opinion: In the Wake of COVID-19, Academia Needs New Solutions to Ensure Gender Equity. PNAS 117:15378-15381.
Mason, Mary Ann, Nicholas H. Wolfinger, and Marc Goulden 2013 Do Babies Matter? Gender and Family in the Ivory Tower. Rutgers University Press, New Brunswick, New Jersey.

Meyers, Maureen S., Elizabeth T. Horton, Edmond A. Boudreaux, and Stephen B. Barmody

2018 The Context and Consequences of Sexual Harassment in Southeastern Archaeology. Advances in Archaeological Practice 6:275-287.

Minello, Alessandra

2020 The Pandemic and the Female Academic. Nature, April 17. DOI: 10.1038/d41586-020-01135-9.

Monroe, Kristen Renwick, and William F. Chiu

2010 Gender Equality in the Academy: The Pipeline Problem. PS: Political Science and Politics 43:303-308.

Moss-Racusin, Corinne A., John F. Dovidio, Victoria L. Brescoll, Mark J. Graham, and Jo Handelsman

2012 Science Faculty's Subtle Gender Biases Favor Male Students. PNAS 109:16474-16479.

Myers, Kyle R., Wei Yang Tham, Yian Yin, Nina Cohodes, Jerry G. Thursby, Marie C. Thursby, Peter Schiffer, Joseph T. Walsh, Karim R. Lakhani, and Dashun Wang

2020 Unequal Effects of the COVID-19 Pandemic on Scientists. Nature Human Behaviour 4:880-883. DOI:10.1038/s41562-020-0921-y.

Nelson, Margaret C., Sarah M. Nelson, and Alison Wylie (editors)

1994 Equity Issues for Women in Archaeology. Archaeological Papers No. 5. American Anthropological Association, Washington, DC.

Nelson, Robin G., Julienne N. Rutherford, Katie Hinde, and Kathryn B. H. Clancy

2017 Signaling Safety: Characterizing Fieldwork Experiences and Their Implications for Career Trajectories. American Anthropologist 119:710-722.

Nokkala, Terhi, Bojana Culum, and Tatiana Fumasoli

2016 Early Career Women in Academia. An Exploration of Networking Perceptions. In The Changing Role of Women in Higher Education, edited by Heather Eggins, pp. 267-290. Springer, Dordrecht, Netherlands.

NSERC-CRSNG

2020 Equity, Diversity and Inclusion: Dimensions. Electronic document, https://www.nserc-crsng.gc.ca/NSERCCRSNG/EDI-EDI/Dimensions_Dimensions_eng.asp, accessed October 20, 2020

Ornstein, Michael, Penni Stewart, and Janice Drakich

2007 Promotion at Canadian Universities: The Intersection of Gender, Discipline, and Institution. Canadian Journal of Higher Education 37(3):1-25.

Parezo, Nancy, and Susan Bender

1994 From Glacial to Chilly Climate: A Comparison between Archaeology and Socio-Cultural Anthropology. In Equity Issues for Women in Archaeology, edited by Sarah M. Nelson, Margaret C. Nelson, and Alison Wylie, pp. 73-81. Archaeological Papers No. 5. American Anthropological Association, Washington, DC.

Radde, Hugh D.

2018 Sexual Harassment among California Archaeologists: Results of the Gender Equity and Sexual Harassment Survey. California Archaeology 10:231-255.

Rautman, Alison E.

2012 Who Gets Published in American Antiquity? SAA Archaeological Record 12(2):25-26, 30.

Rosenfield, Rachel A., and Jo Ann Jones

1987 Patterns and Effects of Geographic Mobility for 
Academic Women and Men. Journal of Higher Education 58:493-515.

Sandberg, Sheryl

2013 Lean In: Women, Work, and the Will to Lead. W. H. Allen, London.

Sandler, Bernice R.

1986 The Campus Climate Revisited: Chilly for Women Faculty, Administrators, and Graduate Students. In Project on the Status and Education of Women, edited by Bernice R. Sandler. Association of American Colleges, Washington, DC.

Schiebinger, Londa

1999 Has Feminism Changed Science? Harvard University Press, Cambridge, Massachusetts.

Smith, Malinda S.

2013 Opening Doors, Closing Gender Gaps: Female and Male Professors by Rank, Diversity and Faculty at the University of Alberta. Report prepared for the Association of Academic Staff University of Alberta, Edmonton, Alberta, Canada.

Speakman, Robert J., Carla S. Hadden, Matthew H. Colvin, Justin Cramb, K. C. Jones, Travis W. Jones, Isabelle Lulewicz, Katharine G. Napora, Katherine L. Reinberger, Brandon T. Ritchison, Alexandra R. Edwards, and Victor D. Thompson

2018 Market Share and Recent Hiring Trends in Anthropology Faculty Positions. PLoS ONE 13(9):e0202528. DOI:10.1371/journal.pone.0202528.

Speakman, Robert J., Carla S. Hadden, Matthew H. Colvin, Justin Cramb, Travis W. Jones, Corbin L. Kling, Isabelle Lulewicz, Katharine G. Napora, Katherine L. Reinberger, Brandon T. Ritchison, Maria Jose Rivera-Araya, April K. Smith, and Victor D. Thompson

2018 Choosing a Path to the Ancient World in a Modern Market: The Reality of Faculty Jobs in Archaeology. American Antiquity 83:1-12.

Staniscuaski, Fernanda, Livia Kmetzsch, Eugenia Zandonà, Fernanda Reichert, Rossana C. Soletti, Zelia M. C. Ludwig, Eliade F. Lima, Adriana Neumann, Ida V. D. Schwartz, Pamela B. Mello-Carpes, Alessandra S. K. Tamajusuku, Fernanda P. Werneck, Felipe K. Ricachenevsky, Camila Infanger, Adriana Seixas, Charley C. Staats, and Leticia de Oliveira

2020 Gender, Race and Parenthood Impact Academic Productivity during the COVID-19 Pandemic: From Survey to Action. bioRxiv, July 4. DOI:10.1101/2020. 07.04.187583.

Stark, Barbara L., Katherine A. Spielmann, Brenda Shears, and Michael A. Ohnersorgen

1997 The Gender Effect on Editorial Boards and in Academia. SAA Bulletin 15(4):6-9.

Statistics Canada

2018 Number and Salaries of Full-Time Teaching Staff at Canadian Universities (final), 2017/2018. Electronic document, https://www150.statcan.gc.ca/n1/daily-quotidien/181115/dq181115b-eng.htm, accessed January 28, 2021

Stewart, Penni, Michael Ornstein, and Janice Drakich

2009 Gender and Promotion at Canadian Universities. Canadian Review of Sociology 46(1):59-85.

Tamblyn, Robyn, Nadyne Girard, Christina J. Qian, and James Hanley

2018 Assessment of Potential Bias in Research Grant Peer Review in Canada. CMAJ 190:E489-E499.

Titone, Debra, Mehrgol Tiv, and Penny M. Pexman

2018 The Status of Women Cognitive Scientists in Canada:
Insights from Publicly Available NSERC Funding Data. Canadian Journal of Experimental Psychology 72(2):81-90.

Tushingham, Shannon, Tiffany Fulkerson, and Katheryn Hill

2017 The Peer Review Gap: A Longitudinal Case Study of Gendered Publishing and Occupational Patterns in a Female-Rich Discipline, Western North America (1974-2016). PLoS ONE 12(11):e0188403. DOI:10. 1371/journal.pone.0188403.

VanDerwarker, Amber M., Kaitlin M. Brown, Toni Gonzalez, and Hugh Radde

2018 The UCSB Gender Equity Project: Taking Stock of Mentorship, Equity, and Harassment in California Archaeology through Qualitative Survey Data. California Archaeology 10:131-158.

Victor, Katherine, and Mary C. Beaudry

1992 Women's Participation in American Prehistoric and Historic Archaeology: A Comparative Look at the Journals American Antiquity and Historical Archaeology. In Exploring Gender through Archaeology, edited by Cheryl Claassen, pp. 11-22. Prehistory Press, Madison, Wisconsin.

Walde, Dale, and Noreen D. Willows

1991 The Archaeology of Gender: Proceedings of the Twenty-Second Annual Conference of the Archaeological Association of the University of Calgary. University of Calgary Archaeological Association, Calgary.

Wolfinger, Nicholas H., Mary Ann Mason, and Marc Goulden

2008 Problems in the Pipeline: Gender, Marriage, and Fertility in the Ivory Tower. Journal of Higher Education 79:388-405.

Wylie, Alison

1993 Workplace Issues for Women in Archaeology. In Women in Archaeology: A Feminist Critique, edited by Hilary du Cros and Laurajane Smith, pp. 245-258. Canberra Department of Prehistory, Research School of Pacific Studies, Australia National University, Canberra.

2011 What Knowers Know Well: Women, Work and the Academy. In Feminist Epistemology and Philosophy of Science: Power in Knowledge, edited by Heidi E. Grasswick, pp. 157-179. Springer, New York.

2013 Why Standpoint Matters. In Science and Other Cultures: Issues in Philosophies of Science and Technology, edited by Sandra Harding and Robert Figueroa, pp. 34 56. Routledge, New York.

Yellen, John E.

1994 Women, Archaeology, and the National Science Foundation: An Analysis of Fiscal Year 1989 Data. In Equity Issues for Women in Archaeology, edited by Sarah M. Nelson, Margaret C. Nelson, and Alison Wylie, pp. 53-57. Archaeological Papers No. 5. American Anthropological Association, Washington, DC.

Zeder, Melinda A.

1997a The American Archaeologist: A Profile. AltaMira, Walnut Creek, California.

1997b The American Archaeologist: Results of the 1994 SAA Census. SAA Bulletin 15(2):12-17.

Zorzin, Nicholas

2010 The Political Economy of a Commercial Archaeology: A Quebec Case Study. PhD dissertation, Department of Archaeology, University of Southhampton, Southhampton, United Kingdom.

Submitted September 3, 2019; Revised August 6, 2020;

Accepted August 11, 2020 